\title{
Oxidative stress and fish immune system: phagocytosis and leukocyte respiratory burst activity
}

\author{
JAQUELINE D. BILLER and LEONARDO S. TAKAHASHI \\ Universidade Estadual Paulista/UNESP, Faculdade de Ciências Agrárias e Tecnológicas/FCAT, Campus de Dracena, \\ Rodovia Comandante João Ribeiro de Barros, Km 651, Bairro das Antas, 17900-000 Dracena, SP, Brazil
}

Manuscript received on September 18, 2017; accepted for publication on February 19, 2018

\begin{abstract}
Molecular oxygen is a necessary compound for all aerobic organisms, although oxygen is a potent oxidant, which can cause oxidative stress (OS). OS occurs when there is an imbalance between the production of oxidant and antioxidants components, are result of normal cell metabolism, and many of these compounds play a fundamental role in several metabolic pathways. The organism produces several reactive oxygen species (ROS), but they are balanced by an antioxidant defense system that maintains the levels of these oxidizing compounds at an acceptable level. Many of these components are essential in the organism defense and their byproducts are considered potent bactericides that actively act in the destruction of invading pathogens. Fish immune system is composed of innate and acquired mechanisms of defense. Phagocytosis is an innate process of defense, which interconnects these two systems, since the pathogens processing by professional phagocytes is a fundamental stage for antibodies production. During phagocytosis there is production of ROS and consequent production of free radicals (FR), these compounds lead to the formation of potent bactericides to combat microorganisms. However, it is known that OS limits the immune response, with an impairment in defense compounds in an attempt to decrease the ROS production. Studies of fish FR production are preliminary and should be executed to evaluate the effects of ROS on fish, including their beneficial action against pathogens and its deleterious action on the oxidation of cellular components.
\end{abstract}

Key words: reactive oxygen species, innate immunity, antioxidant system, free radical.

\section{INTRODUCTION}

Molecular oxygen is a necessary compound for all aerobic organisms, since this element is critical for energy production; however, is a potent oxidant, which can lead to oxidative stress (OS). The reactive oxygen species (ROS) produced and the resulting free radicals (FR) are results of normal cell

Correspondence to: Jaqueline Dalbello Biller

E-mail: jaqueline.biller@unesp.br metabolism, and many of these compounds play a key role in various metabolic pathways. Many of these components are essential in the organism defense and their byproducts are considered potent bactericides that act actively in the destruction of invasive pathogens (Cross et al. 1987, Dong et al. 2017, Biller-Takahashi et al. 2015).

OS occurs when there is an imbalance between the production of oxidant and antioxidant 
components. The organism during its normal metabolism produces several ROSs, however, it has an antioxidant defense system that keeps the levels of these oxidizing compounds at an acceptable level. In some situations the oxidants production is very high and the cells can suffer serious damage and die (Dong et al. 2017, Finkel 2011, Kiley and Storz 2004, Li et al. 2016).

The fish immune system is composed of innate and acquired mechanisms of defense. Phagocytosis is an innate process, which interconnects these two systems, since the pathogens processing by professional phagocytes is a fundamental stage for the antibodies production. During phagocytosis there is the production of ROS and consequent FR, these compounds lead to the formation of potent bactericides compounds to combat microorganisms (Biller-Takahashi et al. 2015, Biller-Takahashi and Urbinati 2014).

Currently, several studies have evaluated the effects of FR on the immune system and new areas of knowledge are being explored, such as immunosenescence, which studies the aging of cells of the immune system caused by FR, as well as inflammasomes, which are biochemical pathways initiated by the activation of receptors that provoke chronic inflammation (genesis of many diseases) (Paiva-Oliveira et al. 2010, Tschopp and Schroder 2010, Angosto and Mulero 2014).

Studies of the fish FR production are preliminary, but there are two factors that positively influence the OS studies in this species; one of them is that fish are considered biological indicators of pollution, which is a factor that promotes the generation of FR by the aquatic organism. Second is that many fish are considered biological models for metabolic pathways evaluation, so, due to the importance of the theme, other studies should be carried out to evaluate the ROS effects on fish, including their beneficial effect against pathogens and deleterious impact on the oxidation of cellular components (Ahmad et al. 2000, Oruc et al. 2004).

\section{OXIDATIVE STRESS}

Oxidative stress is a condition that refers to the imbalance between levels of ROS and their antioxidants. ROS may be increased and damage lipids, proteins and DNA. OS has been linked to a wide variety of diseases; however, ROS molecules also act on immune defense, as well as signaling molecules and on the maintenance of physiological processes (Figure 1) (Wood et al. 2003, Schieber and Chandel 2014).

ROS are involved in energy production, phagocytosis, regulation of cell growth, intercellular signaling and synthesis of important biological substances. They may also be classified as FR, since chemical properties give them reactivity to different biological targets, and when in excess they can cause peroxidation of membrane lipids, impairment of proteins in tissues, membranes, enzymes, carbohydrates and DNA. Even though ROS are evolutionarily selected to modulate immunological and physiological processes (Cross et al. 1987, Dong et al. 2017, Kiley and Storz 2004, Finkel 2011).

FR are highly reactive atoms or molecules that have an unpaired electron in their last electron layer, so, have an unpaired number of electrons in their atomic or molecular orbital. Instability makes atoms or molecules very reactive and therefore can non-specifically bind with other biological molecules. FR can be formed by absorption of ultraviolet radiation or visible light, by redox reactions or by enzymatic catalysis (Ferreira and Matsubara 1997).

ROS are produced mainly in the mitochondria, peroxisomes, cytoplasm and plasma membrane. Oxygen is a birradical that has two radicals in the orbitals, which makes it little reactive, however, the electron transfer or energy absorption processes can promote the ROS formation from molecular oxygen. ROS include oxygen FR, such as the hydroxyl radical $\left(\mathrm{HO}^{\circ}\right)$, superoxide anion $\left(\mathrm{O}_{2}{ }^{\circ}\right)$, 
peroxyl (ROO') and alkoxyl (RO'), nitric oxide (NO), but also non-radical compounds, such as oxygen, hydrogen peroxide $\left(\mathrm{H}_{2} \mathrm{O}_{2}\right)$, hypochlorous acid $(\mathrm{HClO})$, and transition metals $(\mathrm{Cu}$ and $\mathrm{Fe})$ (Sorg 2004, Barreiros et al. 2006).

The FR have a different degree of reactivity and half-life, but most of them are very unstable and can promote the non-enzymatic oxidation of biomolecules (proteins, carbohydrates, lipids and nucleic acids) (Halliwell 2009, Buonocore et al. 2010, Hamanaka and Chandel 2010). Within the cells, there are three main sources of FR formation:

I. Oxidative metabolism in the mitochondria: In the mitochondrial respiratory chain, electron transport is responsible for the ROS formation (Barreiros et al. 2006).

II. Leukocyte respiratory burst activity: neutrophils, monocytes, macrophages, dendritic cells and B-lymphocyte produce ROS, being a strategy of the immune system for several pathogens destruction. The "oxidative burst" is a resting metabolic pathway in the cells, however, it is activated after microbial agent detection. It has the function of producing strong oxidizing compounds (burst activity) that act for microorganisms destruction (Park 2003, Cathcart 2004, Klebanoff 2005, Dale et al. 2008, Biller-Takahashi et al. 2013).

III. Environment: ROS are commonly generated by various environmental factors, dietary, some medications, ultraviolet and visible light and ionizing radiation. The cumulative action of the FR over the years is the cause of aging, genetic mutations and oncogenesis (Burke and Wei 2009).

Among the ROS, the hydroxyl radical (HO') is the most harmful, because there is great difficulty in its sequestration out of the cells due to its very short half-life. This FR is formed in the body by reaction of $\mathrm{H}_{2} \mathrm{O}_{2}$ with transition metals and by homolysis of water by exposure to ionizing radiation. There is no antioxidant capable of preventing the $\mathrm{HO}^{\circ}$ action, it is only possible to inhibit its formation or repair the damage caused by it (Halliwell et al. 1992, Barreiros et al. 2006).

The superoxide anion radical $\left(\mathrm{O}_{2}^{-{ }^{-}}\right)$is usually inactive, and in aqueous media produces a hydrogen peroxide molecule and an oxygen molecule by dismutation. This FR is part of several chemical reactions with important biological functions, such as $\mathrm{HO}^{\circ}$ radical production, by reducing Fe chelates, as well as $\mathrm{Fe}^{2+}$ released from storage proteins (ferritin and aconitase) and iron-sulfoproteins, in addition to reacting with the $\mathrm{HO}^{\circ}$ radical producing singlet oxygen $\left({ }^{1} \mathrm{O}_{2}\right)$ and reacting with nitric oxide $\left(\mathrm{NO}^{\circ}\right)$ producing peroxynitrite $\left(\mathrm{ONOO}^{-}\right)$(Babior 1997, Halliwell 2000, Barreiros et al. 2006).

The superoxide radical, in spite of its deleterious effects, has important function for immune defense, because in phagocytic cells, lymphocytes and fibroblasts, the $\mathrm{O}_{2}{ }^{--}$has the capacity to destroy pathogens. The $\mathrm{O}_{2}{ }^{--}$produced in the cells can be eliminated by the superoxide dismutase enzyme, which catalyzes the dismutation of two molecules of $\mathrm{O}_{2}^{-}{ }^{-}$in oxygen and hydrogen peroxide, however, when there is no enzymatic elimination (peroxidases and catalase), this FR can lead to formation of hydroxyl radicals (Babior 1997, Halliwell 2000, Barreiros et al. 2006, Li et al. 2016, Dong et al. 2017).

$\mathrm{H}_{2} \mathrm{O}_{2}$ is a poorly reactive non-radical compound that can easily diffuse through cell membranes, and consequently promote the formation of the $\mathrm{HO}^{\circ}$ radical after binding with transition metals, which are usually present within the cell. This FR is generated by the dismutation of the superoxide anion by oxidases enzymes, or even through the oxidation of fatty acids. Hydrogen peroxide in the mitochondrial matrix is produced in abundance during the $\mathrm{O}_{2}$ reduction process but can be partially eliminated by the catalase, glutathione peroxidase enzymes and peroxidases bound to thioredoxin, or it may be further released into the cell cytoplasm. In phagocytes, $\mathrm{H}_{2} \mathrm{O}_{2}$ is a precursor of hypoalogens acids that are strong oxidants against pathogens, 


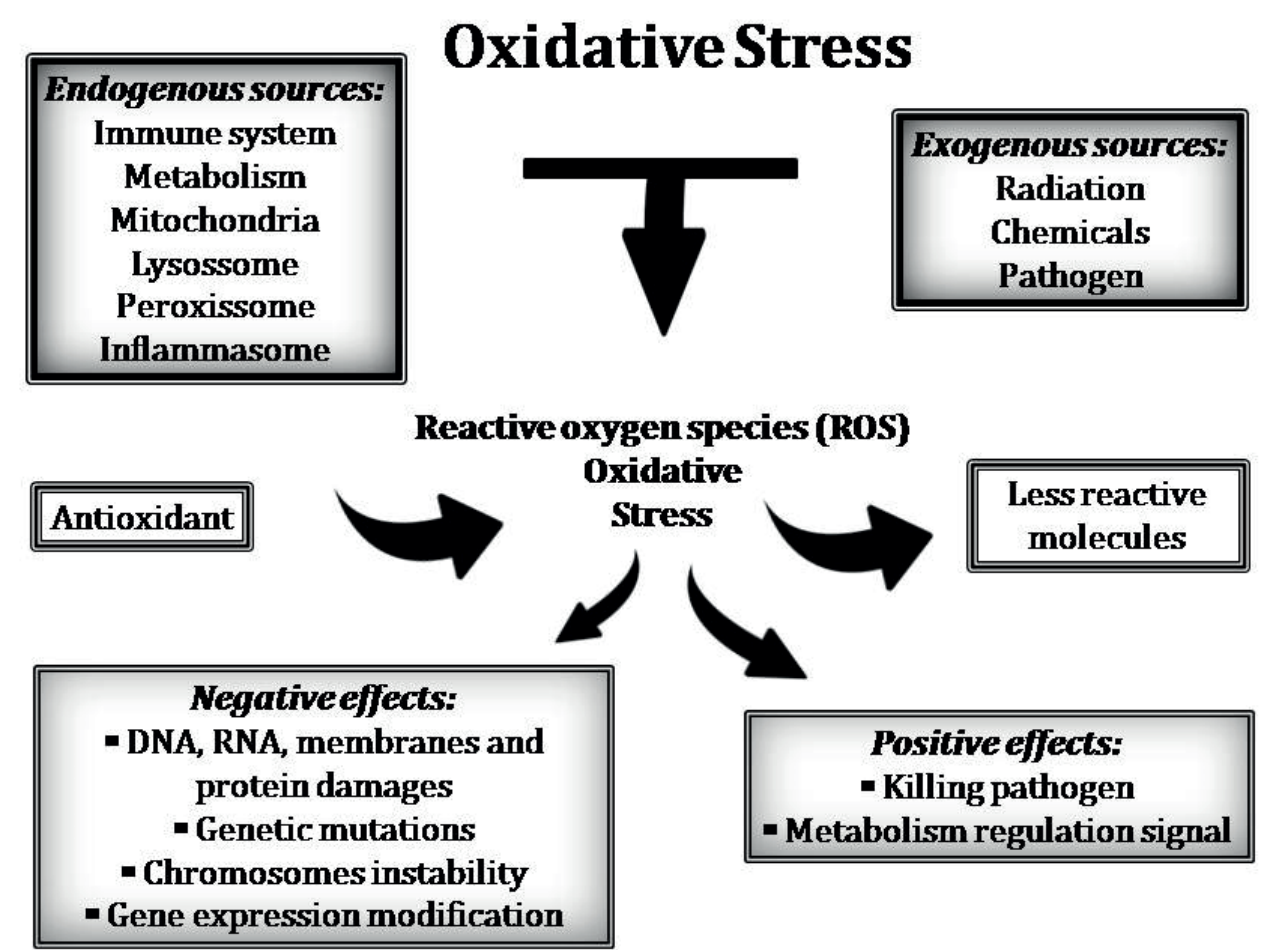

Figure 1 - The concept of the oxidative stress effects.

but also acts deleteriously on molecules of the organism itself (Husain et al. 1987, Vogt 1995, Halliwell 2000).

\section{ANTIOXIDANT DEFENSE SYSTEM}

The organism, in the face of the imbalance of FR production, presents a strategy to inhibit its formation or to promote chemical reactions to reduce the high reactivity of these compounds through antioxidant components, such as enzymes or cofactors, obtained by the cell itself (endogenous source) or through diet (exogenous source). Antioxidants are substances that significantly delay or prevent the oxidation of an oxidizable substrate (Franco and Martínez-Pinilla 2017, Sorg 2004, Wang et al. 2013). Many studies have been conducted on fish to evaluate their antioxidant compounds to determine a database for comparative studies on the effects of natural environment, diet, seasonal variation, xenobiotics and others (Mattos et al. 2017, Moura et al. 2017,
Winston 1991, Halliwell et al. 1995, Pietta 2000, Li et al. 2016).

The antioxidants produced by the body act enzymatically by decreasing the excess of FR, through enzymatic components, such as the superoxide dismutase (SOD), catalase (CAT) and glutathione peroxidase (GPx) enzymes and through non-enzymatic components such as glutathione (GSH), histidine peptides, iron-bound proteins (transferrin and ferritin), dihydrolipoic acid and ubiquinone $\left(\mathrm{CoQH}_{2}\right)$. And some dietary antioxidants such as $\alpha$-tocopherol (vitamin-E), $\beta$-carotene (pro-vitamin-A), ascorbic acid (vitamin C), micronutrients (selenium) and phenolic compounds, such as flavonoids and polyflavonoids (Albuquerque et al. 2017, Halliwell et al. 1995, Pietta 2000).

Traditional pesticides, such as organochlorines, organophosphates and carbamates are known to be hazardous due to their polluting effects on the environment and on animal organism, leading 
to changes in DNA, ROS and FR generation, alterations on the antioxidant defense system, such as enzymes inhibition, gene expression and the production of heat shock proteins (Arantes et al. 2016, Guardiola et al. 2014, Freeman et al. 1982, Ekinci and Beydemir 2010).

Fish present a complex antioxidant defense system that comprises several enzymes, among them SOD is widely found in the cytosol $\left(\mathrm{Cu}^{2+}\right.$ SOD and $\mathrm{Zn}^{2+}$-SOD) and in the mitochondria $\left(\mathrm{Mn}^{2+}-\mathrm{SOD}\right)$, that acts on the superoxide anion transforming in $\mathrm{H}_{2} \mathrm{O}_{2}$, avoiding the accumulation of $\mathrm{O}_{2}{ }^{-}$, which is highly reactive and deleterious to the cell. The produced $\mathrm{H}_{2} \mathrm{O}_{2}$ can be eliminated by catalases, GPx and peroxidases bound to thioredoxin, or it may be further released into the cytoplasm of cells (Lambeth 2004, Brand 2010, Schieber and Chandel 2014, Li et al. 2016). CAT (derived from mitochondria and peroxisomes) catalyzes the decomposition of $\mathrm{H}_{2} \mathrm{O}_{2}$ into $\mathrm{H}_{2} \mathrm{O}$ and $\mathrm{O}_{2}$, which is produced in abundance by phagocytes, and maintains the ideal balance of ROS formation and elimination, essential for the functioning of the innate defense system. Modulation of CAT production is important for many processes, such as proliferation, differentiation, cell migration and apoptosis (Underhill and Ozinsky 2002, Oost et al. 2003, Malhotra and Kaufman 2007, Veal et al. 2007, Zamocky et al. 2008, Wang et al. 2013).

$\mathrm{H}_{2} \mathrm{O}_{2}$ can also be neutralized by cytosolic or mitochondrial GPx in the presence of GSH. GSH also contributes to the removal of electrophilic components through the reaction with glutathioneS-transferase. The antioxidant system based on GSH acts in the presence of selenium, which is a very important micronutrient and widely studied in fish. GPx plays an important role in the prevention of lipid peroxidation, since it removes $\mathrm{H}_{2} \mathrm{O}_{2}$, consequently protects the membranes from peroxidation damage (Sies 1986, Gaté et al. 1999, Oost et al. 2003, Scandalios 2005, Monteiro et al. 2006).
Antioxidants from diet are important to avoid the ROS effects (Lambeth 2004, Brand 2010). Ascorbic acid or vitamin C normally appears in the body as ascorbate form and is an excellent antioxidant in vivo, as it can be oxidized by most of the FR in aqueous solution, and converted into poorly reactive substances. Vitamin $\mathrm{C}$ acts by binding to ROS present in the body and restoring the FR through $\mathrm{H}^{+}$donation, in cell membranes it acts together with vitamin $\mathrm{E}$, regenerating the Vit $\mathrm{E}$ after ROS interaction. Vitamin $\mathrm{C}$ also acts as a reductor agent, mainly decreasing transition metals such as $\mathrm{Fe}$ and $\mathrm{Cu}$ ions that react with $\mathrm{H}_{2} \mathrm{O}_{2}$ to form the hydroxyl radical (Buettner 1993, Babior 1997).

Vitamin E, in vivo, is a potent inhibitor of lipid peroxidation. It acts as an $\mathrm{H}^{+}$donor for the peroxyl radical, interrupting the $\mathrm{FR}$ formation chain reaction. The $\mathrm{H}^{+}$donation leads vitamin $\mathrm{E}$ loss of function, however, it can be regenerated with vitamin $\mathrm{C}$. The impact of the vitamin E on fish immune system have been extensively studied (Storey 1996, Theriault et al. 1999, Monteiro et al. 2006).

Selenium (Se), an essential micronutrient, is an integral part of several selenium-enzymes, among them GPx, iodothyronine deiodinase, thioredoxin reductase and selenophosphate synthetase. Selenium-enzymes is included on antioxidant defense system compound, as well as on metabolism of thyroid hormones, spermatogenesis and other biological processes, and it has been the subject of many studies on fish immune system. Some studies have demonstrated an improvement of humoral and cell-mediated immune responses following the selenium incorporation into the diet of fish (Hsu and Guo 2002, Biller-Takahashi et al. 2015, Chien et al. 2003).

Enzymatic and non-enzymatic antioxidants are essential to maintain the balance between production and elimination of FR from fish cells. Antioxidants are an important biological defense against OS involved in cell detoxification, and are very important for understanding the deleterious 
effects of FR (Bainy 1996, Doyotte et al. 1997, Ahmad et al. 2000, Oruc et al. 2004).

\section{FISH IMMUNE SYSTEM}

The immune system comprises a set of cellular and humoral components that act to defend the body against foreign substances, such as microorganisms, toxins or malignant cells, responding to any factors, both exogenous and endogenous, that stimulate the components of this system (Figure 2) (Bayne and Gerwick 2001, Biller-Takahashi and Urbinati 2014).

The immune system of fish is divided into innate and acquired, which act together to destroy invaders or trigger defensive processes. The innate system includes all the components present in the organism before the pathogen invasion, forming the first organic defense barrier that acts more quickly and continuosly to maintain the organism homeostasis. Includes the components, such as the skin, as a physical barrier, besides the complement system, antimicrobial enzyme system and nonspecific mediators such as interferon, interleukins and organic defense cells, such as granulocytes, monocytes, macrophages and natural killer cells (Ellis 1999). The defense cells present highly reactive ROS that will attack the membranes of invading microorganisms in an unspecific way and thus contribute to their destruction (BillerTakahashi et al. 2013).

The innate system is the oldest on the phylogenetic scale and has emerged in unicellular organisms during the evolutionary period. By definition, this system recognizes regions (Pamps - Pathogen associated molecular patterns) of pathogens associated with infectious agents or microorganisms of the normal microbiota, such as lipopolysaccharides, peptidoglycans, bacterial DNA or viral RNA, or other molecules of multicellular microorganisms membranes ("Non-self") through innate receptors (PRRs Pattern recognition receptors), never recognizing components of the body itself. Pamps are usually highly conserved portions during species evolution and are present in the majority of microorganisms (Janeway 1989, Goldsby et al. 2002, Elward and Gasque 2003).

The specific immune system emerged afterwards, around 450 million years ago, and can be found in all vertebrates, except in the Agnatha Class (Holland and Lambris 2002). The receptors of the acquired system responsible for detecting the invading agent are found on the membrane of immunocompetent cells, T lymphocytes (TCR) and B lymphocytes (BCR, surface immunoglobulin) and when stimulated they promote increase of circulating specific antibodies for such invaders, in addition, promoting immune memory (Abbas and Lichtman 2004, Bernstein et al. 1998, Delves and Roitt 2000a, b).

\section{OXIDATIVE STRESS AND IMMUNE SYSTEM OF FISH}

ROS are fundamental for modulation of the immune system, although it is known that the production of the immune compounds in fish is limited by oxidative stress. While there is an imbalance between the oxidant and the antioxidant production, detected by low concentrations of antioxidant enzymes, the immune system responses are lower, probably in an attempt to avoid the excessive ROS production (Biller-Takahashi et al. 2015).

The pathogens recognition and processing by phagocytes produces ROS, and after reaction with NADPH oxidase, in the process known as "oxidative burst", there are the production of FR with bactericidal activity. For example, $\mathrm{O}_{2}{ }^{\text {- }}$ is considered a weak bactericidal agent that acts on bacterial proteins, however, it can lead to the compounds formation with potent bactericidal action, such as $\mathrm{HClO}, \mathrm{H}_{2} \mathrm{O}_{2}$ and $\mathrm{ONOO}^{-}$(Pawelec et al. 2011, Shaw et al. 2010, Canizzo et al. 2011). ROS are also involved in the signaling of injuries to the immune system, for example, injured tissues 


\section{FISH IMMUNE SYSTEM}

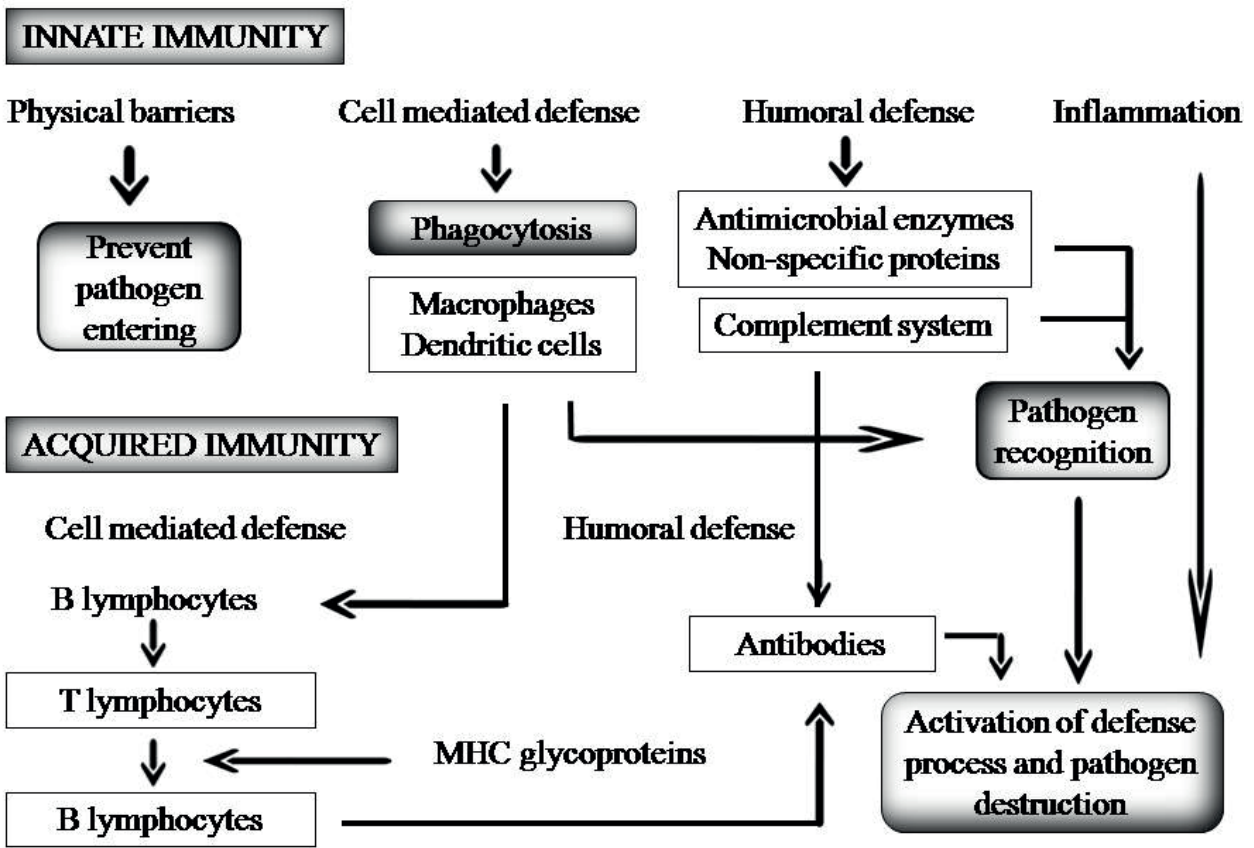

Figure 2 - The concept of fish immune system (Biller-Takahashi and Urbinati 2014).

release $\mathrm{H}_{2} \mathrm{O}_{2}$, which promotes chemotaxis and migration of leukocytes to the focus of the lesion (Biller-Takahashi et al. 2015, Bogdan et al. 2000, Ma and Berkowitz 2007, Niethammer et al. 2009, Martinon 2010).

The presence of ROS in the cells triggers biochemical reactions that will culminate in decreased cellular function due to oxidative damage caused in proteins, carbohydrates and lipids, which can lead to apoptosis and accumulation of oxidized molecular aggregates. Aged cells decrease the production of antioxidative enzymes, such as SOD, CAT and GPx and increase the accumulation of FR; for example macrophages, when aged present a reduction of the Mn-SOD enzyme, and becomes vulnerable to apoptosis induced by lipid peroxidation (Scandalios 2005, Canizzo et al. 2011).

The presence of FR induces the constant activation of granulocytes, macrophages and dendritic cells, with permanent production of ROS due to the leukocytes respiratory burst activity, as well as the consequent activation of the innate defense compounds, such as activation of the complement system proteins and expression of adhesion proteins in leukocytes. In some cases this constant activation can promote the immune system exhaustion (Vider et al. 2001, Lotze et al. 2007, Gill et al. 2010).

Recently, the immune system modulation by inflammasomes have been studied. Inflammasomes are intracellular multiprotein complexes that activate enzymes (caspases) through the receptors stimulation, such as the Pamps and Damps ("damage-associated molecular patterns"), and will promote inflammation. ROS formed in this system are part of biochemical reactions of signaling, and can also activate inflammation, via inflammasomes, which leads to the production of various proinflammatory immune cytokines such as interleukins (Paiva-Oliveira et al. 2010, Tschopp and Schroder 2010, Angosto and Mulero 2014). "NOD like" receptors (NLRs) of fish have been used as biological inflammasomes model in order 
to understand their evolution (Paiva-Oliveira et al. 2010, Tschopp and Schroder 2010, Angosto and Mulero 2014).

NLRs are Pamps and Damps receptors that induce the ROS production. Among ROS that signal the biochemical pathway, $\mathrm{H}_{2} \mathrm{O}_{2}$ is the second messenger responsible for the reactions that can culminate in apoptosis, necrosis, cell regulation and inflammation. However, ROS action is strictly controlled by the antioxidant system, and an imbalance will trigger cellular damages caused by the FR action and the inflammasomes activation (Martinon 2010, Tschopp and Schroder 2010).

Environmental factors may also promote diseases involving the immune system and oxidative stress, since several xenobiotics can cause $\mathrm{OS}$ and ROS generation, such as $\mathrm{HO}^{\circ}, \mathrm{O}_{2}{ }^{--}$and $\mathrm{H}_{2} \mathrm{O}_{2}$, besides changes in the antioxidant enzymes production and consequent lipid peroxidation. The ROS production stimulated by xenobiotics promote fish diseases and toxicity in aquatic organisms exposed to pollutants (Kehrer 1993, Livingstone et al. 1993, Banerjee et al. 1999, Livingstone 2001, Nordberg and Arnér 2001, Shi et al. 2005).

Fish are constantly challenged by microorganisms or pollutants, as well as byproducts produced by the metabolism itself, such as FR, however, these animals present an apparatus to respond and repair the damage caused in the intra and extracellular media. The ability to identify and respond to aggressions occurs because these hazards are recognized by many types of receptors, including "Toll Like" Receptors (TLRs) and NLRs that modulate cascades of reactions that culminate in problem resolution or cell death (Tschopp and Schroder 2010).

PHAGOCYTOSIS AND LEUKOCYTES RESPIRATORY BURST ACTIVITY

Phagocytosis is an essential mechanism of the innate immune system. During this process, membrane receptors recognize the invading agent and involve them by invaginations of the cytoplasmic membrane, and inside the cell these vacuoles bind to the lysosomes forming the phagosomes, that will digest and culminate in microorganism destruction. After that, there is a possibility of antigen presentation to cells of the acquired system in order to induce the release of specific antibodies, besides restructuring the injured tissue (Underhill and Ozinsky 2002, Lambeth 2004).

The activation of phagocytes after pathogen recognition promotes morphological, physiological and biochemical alterations, including increase in cell size and enzymatic activity, as well as the expression of intracellular proteins that enable the cell to present germicidal activity (Enane et al. 1993). Phagocytosis has been used as a parameter to evaluate the immunological status in several fish species, under the influence of different factors such as pollutants, diets, temperature, pathogens and genetic variation (Weeks and Warinner 1986, Blazer 1991, Hardie et al. 1994, Sarder et al. 2001, Jensch-Junior et al. 2006).

Phagocytosis is one of the most important defense mechanisms in fish and may promote the production of specific immunoglobulins (Neumann et al. 2001). Neutrophils, macrophages, dendritic cells and monocytes are professional phagocytes and ROS producers in a process known as leukocyte respiratory burst activity (BillerTakahashi et al. 2013). Following pathogens recognition, these phagocytes release cytokines, which are inflammatory signaling proteins, into the injured tissue in order to promote the chemotaxis and mobilization of other defense phagocytes and proteins to prevent the disease spread (Stuart and Ezekowitz 2005, Biller-Takahashi et al. 2013).

The leukocyte respiratory burst activity has been used as an indicator of innate immunity, and was first observed in mammals in the 1930s, when some researchers observed that during phagocytosis there was a high oxygen consumption. Higson and Jones (1984) demonstrated that rainbow trout 
phagocytes produced superoxide anion $\left(\mathrm{O}_{2}{ }^{-}\right)$and hydrogen peroxide $\left(\mathrm{H}_{2} \mathrm{O}_{2}\right)$ after stimulation with phorbol myristate (PMA) and "brushite" (calcium phosphate), soluble and particulate, respectively, which activate human neutrophils. Currently, this defense process is well elucidated, and due to $\mathrm{O}_{2}$ consumption, is known as oxidative burst and is correlated with cytokine release and inflammatory response in fish (Baldridge and Gerard 1933, BillerTakahashi et al. 2013).

During pathogens phagocytosis, leukocytes increase their consumption of intracellular oxygen and consequently there is production of several ROS. Initially due to the enzyme NADPH oxidase action, $\mathrm{O}_{2}$ is oxidized in $\mathrm{O}_{2}{ }^{--}$, and after SOD action, leads to the formation of hydrogen peroxide. $\mathrm{H}_{2} \mathrm{O}_{2}$ can undergo Fenton reaction $\left(\mathrm{Fe}^{2+}\right.$ reaction with $\mathrm{H}_{2} \mathrm{O}_{2}, \mathrm{Fe}$ is released from the storage proteins by the action of $\mathrm{O}_{2}{ }^{-}$), which leads to the formation of the hydroxyl radical, or can be part of other biochemical reactions to form hypoalogens acids, which are potent oxidant compounds against microorganisms (Vogt 1995, Halliwell 2000, BillerTakahashi et al. 2013).

The hydroxyl radical (HO') produced during phagocytosis can react with amino acids and proteins of the microorganisms damaging the biochemical bonds and as a result, inactivate the enzymatic activity, alter the active transport through the cell membranes, cause cytolysis and cellular destruction, however, $\mathrm{HO}^{\circ}$ can react with the superoxide anion radical and produce singlet oxygen $\left({ }^{-1} \mathrm{O}_{2}\right)$, which is the most deleterious oxygen form. Produced $\mathrm{O}_{2}{ }^{--}$can participate in reactions with other molecules such as NO and produce peroxynitrite, chloramines and consequently hypochlorous acid or hypochlorite (catalyzed by myeloperoxidase, an enzyme present exclusively in cells of the innate immune system (Barreiros et al. 2006, Biller-Takahashi et al. 2013)).

The $\mathrm{O}_{2}^{--}$is fundamental for protection against pathogens and organism survival, due to its importance to the immune system, especially during the inflammatory process. $\mathrm{O}_{2}{ }^{-}$is highly reactive and deleterious to cells in general, and is correlated with many diseases (Babior 1997, Halliwell 2000, Barreiros et al. 2006). All ROS produced during phagocytosis and their byproducts are very toxic and will be the basis of an effective oxidizing defense system against microorganisms. Oxidative burst is a resting metabolic pathway in cells but is activated after microbial invasion, however, the production of ROS can vary during the periods of the year, or even the day, since it can be regulated by temperature and circadian rhythms (Vogt 1995, Biller-Takahashi et al. 2013).

\section{FUTURE PERSPECTIVES}

Oxidative stress is a very important issue considering the problem of the aquatic environment contamination with pesticides and their consequences on the immune system. ROS are involved in several mechanisms, resulting in the formation of potent bactericidal compounds, however, they are involved in cellular aging and in the installation of chronic inflammation, which are the causal agents of many diseases. Several studies have already been carried out on native fishes, mainly with evaluation of the interaction of oxidative stress and immune system on aquatic organisms. However, due to the importance of the theme, further studies should be carried out to better understand the impacts of oxidative stress on fish.

\section{REFERENCES}

ABBAS AK AND LICHTMAN AH. 2004. Basic Immunology. Functions and disorders of the immune system. Saunders Company, $319 \mathrm{p}$.

AHMAD I, HAMID T, FATIMA M, CHAND HS, JAIN SK, ATHAR M AND RAISUDDIN S. 2000. Induction of hepatic antioxidants in freshwater catfish (Channa punctatus Bloch) is a biomarker of paper mill effluent exposure. Biochim Biophys Acta 1519: 37-48.

ALBUQUERQUE DMN, LOPES JB, FERRAZ MS, RIBEIRO MN, SILVA SRG, COSTA EMS, LIMA DCP, FERREIRA JDM, GOMES PEB AND LOPES JCO. 2017. Vitamin E and organic selenium for broilers from 22 to 42 
days old: performance and carcass traits. An Acad Bras Cienc 89: 1259-1268.

ANGOSTO D AND MULERO V. 2014. The zebrafish as a model to study the Inflammasome. Inflammasome 1: 2729.

ARANTES FP, SAVASSI LA, SANTOS HB, GOMES MVT AND BAZZOLI N. 2016. Bioaccumulation of mercury, cadmium, zinc, chromium, and lead in muscle, liver, and spleen tissues of a large commercially valuable catfish species from Brazil. An Acad Bras Cienc 88: 137-147.

BABIOR BM. 1997. Superoxide: a two-edged sword. Braz J Med Biol Res 30: 141-155.

BAINY ACD. 1996. Oxidative stress as biomarker of polluted aquatic sites. In: Val AL, Almeida-Val VMF and Randall DJ (Eds), Physiology and Biochemistry of the Fishes of the Amazon. INPA, Manaus, Brazil, p. 101-110.

BALDRIDGE CW AND GERARD RW. 1933. The extra respiration of phagocytosis. Am J Physiol 103: 235-236.

BANERJEE BD, SETH V, BHATTACHARYA A, PASHA ST AND CHAKRABORTY AK. 1999. Biochemical effects of some pesticides on lipid peroxidation and freeradical scavengers. Toxicol Lett 107: 33-47.

BARREIROS ALBS, DAVID JM AND DAVID JP. 2006. Estresse oxidativo: relação entre geração de espécies reativas e defesa do organismo. Quim Nova 29: 113-123.

BAYNE CJ AND GERWICK L. 2001. The acute phase response and innate immunity of fish. Develop Comp Immunol 25: 725-743.

BERNSTEIN RM, SCHLUTER SF AND MARCHALONIS JJ. 1998. Immunity. In: Evans DH. The physiology of fishes, $2^{\text {nd }}$ ed., Boca Raton: CRC Press, p. 215-242.

BILLER-TAKAHASHI JD, TAKAHASHI LS, MINGATTO FE AND URBINATI EC. 2015. The immune system is limited by oxidative stress: dietary selenium promotes optimal antioxidative status and greatest immune defense in pacu Piaractus mesopotamicus. Fish Shellfish Immunol 47: 360-367.

BILLER-TAKAHASHI JD, TAKAHASHI LS, SAITA MV, GIMBO RY AND URBINATI EC. 2013. Leukocytes respiratory burst activity as indicator of innate immunity of pacu Piaractus mesopotamicus. Braz J Biol 73: 425429.

BILLER-TAKAHASHI JD AND URBINATI EC. 2014. Fish Immunology. The modification and manipulation of the innate immune system: Brazilian studies. Braz J Biol 86: 75-87.

BLAZER VS. 1991. Piscine macrophage function and nutritional influences: a review. J Aquat Anim Health 3: 77-86.

BOGDAN C, ROLLINGHOFF M AND DIEFENBACH A. 2000. Reactive oxygen and reactive nitrogen intermediates in innate and specific immunity. Curr Opin Immunol 12: 64-76.
BRAND M. 2010. The sites and topology of mitochondrial superoxide production. Exp Gerontol 45: 466-472.

BUETTNER GR. 1993. The pecking order of free radicals and antioxidants: Lipid peroxidation, -tocopherol, and ascorbate. Arch Biochem Biophys 300: 535-543.

BUONOCORE G, PERRONE S AND TATARANNO ML. 2010. Oxygen toxicity: chemistry and biology of reactive oxygen species. Semin Fetal Neonatal Med 15: 186-190.

BURKE KE AND WEI H. 2009. Synergistic damage by UVA radiation and pollutants. Toxicol Ind Health 25: 219-224.

CANNIZZO ES, CLEMENTA CC, SAHUA R, FOLLO C AND SANTAMBROGIO L. 2011. Oxidative stress, inflamm-aging and immunosenescence. J Proteomics 74: 2313-2323.

CATHCART MK. 2004. Regulation of superoxide anion production by NADPH oxidase in monocytes/ macrophages: contributions to atherosclerosis. Arterioscler Thromb Vasc Biol 24: 23-28.

CHIEN LC, YEH CY, HUANG SH, SHIEH MJ AND HAN BC. 2003. Pharmacokinetic model of daily selenium intake from contaminated seafood in Taiwan. Sci Total Environ 311: 57-64.

CROSS CE, HALLIWELL B, BORISH ET, PRYOR WA, AMES BN, SAUL RL, MCCORD JM AND HARMAN D. 1987. Oxygen radicals and human disease. Ann Int Med 107: 526-545.

DALE DC, BOXER LAND LILES WC. 2008. The phagocytes: neutrophils and monocytes. Blood 112: 935-945.

DELVES PJ AND ROITT IM. 2000a. The immune system: first of two parts. New Engl J Med 343: 37-49.

DELVES PJ AND ROITT IM. 2000b. The immune system: second of two parts. New Engl Med 343: 108-117.

DONG M, LIANG Y, RAMALINGAM R, TANG SW, SHEN W, YE R, GOPALAKRISHNAN S, AU DWT AND LAM YW. 2017. Proteomic characterization of the interactions between fish serum proteins and waterborne bacteria reveals the suppression of antioxidative defense as a serum-mediated antimicrobial mechanism. Fish Shellfish Immunol 62: 96-106.

DOYOTTE A, COSSU C, JACQUIN MC, BABUT M AND VASSEUR P. 1997. Antioxidant enzymes, glutathione and lipid peroxidation as relevant biomarkers or experimental or field exposure in the gills and the digestive gland of the freshwater bivalve Unio tumidus. Aquat Toxicol 39: 93-110.

EKINCI D AND BEYDEMIR S. 2010. Risk assessment of pesticides and fungicides for acidbase regulation and salt transport in rainbow trout tissues. Pestic Biochem Phys 97: 66-70.

ELLIS AE. 1999. Immunity to bacteria in fish. Fish Shellfish Immunol 9: 291-308.

ELWARD K AND GASQUE P. 2003. "Eat me" and "don't eat me" signals govern the innate immune response and 
tissue repair in the CNS: emphasis on the critical role of the complement system. Mol Immunol 40: 85-94.

ENANE NA, FRENKEL K, O'CONNOR JM, SQUIBB KS AND ZELIKOFF JT. 1993. Biological markers of macrophage activation: applications for fish phagocytes. Immunology 80: 68-72.

FERREIRA ALA AND MATSUBARA LS. 1997. Radicais livres: conceitos, doenças relacionadas, sistema de defesa e estresse oxidativo. Rev Ass Med Brasil 43: 61-68.

FINKEL T. 2011. Signal transduction by reactive oxygen species. J Cell Biol 194: 7-15.

FRANCO R AND MARTÍNEZ-PINILLA E. 2017. Chemical rules on the assessment of antioxidant potential in food and food additives aimed at reducing oxidative stress and neurodegeneration. Food Chem 235: 318-323.

FREEMAN BA AND CRAPO JD. 1982. Biology of disease: free radicals and tissue injury. Lab Invest 47: 412-26.

GATÉ L, PAUL J, NGUYEN BAC, TEW KD AND TAPIERO H. 1999. Oxidative stress induced in pathologies: the role of antioxidants. Biomed Pharmac 53: 169-180.

GILL R, TSUNG A AND BILLIAR T. 2010. Linking oxidative stress to inflammation: toll-like receptors. Free Radic Biol Med 48: 1121-1132.

GOLDSBY RA, KINDT TJ, OSBORNE BA AND KUBY J. 2002. In: Immunology, $5^{\text {th }}$ ed., WH Freeman \& Company Publisher, $554 \mathrm{p}$.

GUARDIOLA FA, GÓNZALEZ-PÁRRAGA P, MESEGUER J, CUESTA A AND ESTEBAN MA. 2014. Modulatory effects of deltamethrin-exposure on the immune status, metabolism and oxidative stress in gilthead seabream (Sparus aurata L.). Fish Shellfish Immunol 36: 120-129.

HALLIWELL B. 2000. The antioxidant paradox. The Lancet 355: 1179-1187.

HALLIWELL B. 2009. The wanderings of a free radical. Free Radic Biol Med 46: 531-542.

HALLIWELL B, AESCHBACH R, LOLIGER J AND AROUMA OI. 1995. The Characterization of Antioxidants. Food Chem Toxicol 33: 601-612.

HALLIWELL B, GUTTERIDGE JMC AND CROSS CE. 1992. Free radicals, antioxidants, and human disease. Where are we now? J Lab Clin Med 119: 598-620.

HAMANAKA RB AND CHANDEL NS. 2010. Mitochondrial reactive oxygen species regulate cellular signaling and dictate biological outcomes. Trends Biochem Sci 35: 505513.

HARDIE LJ, FLETCHER TC AND SECOMBES CJ. 1994. Effect of temperature on macrophage activation and the production of macrophage activating factor by rainbow trout (Oncorhynchus mykiss) leucocytes. Dev Comp Immunol 18: 57-66.

HIGSON FK AND JONES OTG. 1984. The generation of active oxygen species by stimulated rainbow trout leucocytes in whole blood. Comp Biochem Physiol 77B: 583-587.
HOLLAND MCH AND LAMBRIS JD. 2002. The complement system in teleosts. Fish Shellfish Immunol 12: 399-420.

HSU PC AND GUO YL. 2002. Antioxidant nutrients and lead toxicity. Toxicol 180: 33-44.

HUSAIN SR, CILLARD J AND CILLARD P. 1987. Hydroxyl radical scavenging activity of flavonoids. Phytochemistry 26: 2489-2497.

JANEWAY C. 1989. Immunogenicity signals. Immunol Today 10: 283-286.

JENSCH-JUNIOR BE, PRESSINOTTI LN, BORGES JCS AND SILVA JRMC. 2006. Characterization of macrophage phagocytosis of the tropical fish Prochilodus scrofa (Steindachner, 1881). Aquaculture 251: 509-515.

KEHRER JP. 1993. Free radicals as mediators of tissue injury and disease. Crit Rev Toxicol 34: 21-48.

KILEY PJ AND STORZ G. 2004. Exploiting thiol modifications. PLoS Biol 2: 391-400.

KLEBANOFF SJ. 2005. Myeloperoxidase: friend and foe. J Leukoc Biol 77: 598-625.

LAMBETH JD. 2004. NOX enzymes and the biology of reactive oxygen. Nat Rev Immunol 4: 181-189.

LI H, JIANG W, LIU Y, JIANG J, ZHANG Y, WU P, ZHAO J, DUAN X, ZHOU X AND FENG L. 2016. The metabolites of glutamine prevent hydroxyl radical-induced apoptosis through inhibiting mitochondria and calcium ion involved pathways in fish erythrocytes. Free Rad Biol Med 92: 126140.

LIVINGSTONE DR. 2001. Contaminant-stimulated reactive oxygen species production and oxidative damage in aquatic organisms. Mar Pollut Bull 42: 656-666.

LIVINGSTONE DR, LEMAIRE P, MATTHEWS A, PETERS L, BUCKE D AND LAW RJ. 1993. Pro-oxidant, antioxidant and 7-ethoxyresorufin O-deethylase (EROD) activity responses in liver of dab (Limanda limanda) exposed to sediment contaminated with hydrocarbons and other chemicals. Mar Pollut Bull 26: 602-606.

LOTZE MT, ZEH HJ, RUBARTELLI A, SPARVERO LJ, AMOSCATO AA, WASHBURN NR, DEVERA ME, LIANG X, TÖR M AND BILLIAR T. 2007. The grateful dead: damage-associated molecular pattern molecules and reduction/oxidation regulate immunity. Immunol Rev 220: 60-81.

MA W AND BERKOWITZ GA. 2007. The grateful dead: calcium and cell death in plant innate immunity. Cell Microbiol 9: 2571-2585.

MALHOTRA JD AND KAUFMAN RJ. 2007. Endoplasmic reticulum stress and oxidative stress: a vicious cycle or a double-edged sword? Antioxid Redox Signal 9: 22772293.

MARTINON F. 2010. Signaling by ROS drives inflammasome activation. Eur J Immunol 40: 595-653.

MATTOS BO, NASCIMENTO FILHO ECT, SANTOS AA, BARRETO KA, SÁNCHEZ-VÁZQUEZ FJ AND 
ORTES-SILVA R. 2017. A new approach to feed frequency studies and protein intake regulation in juvenile pirarucu. An Acad Bras Cienc 89: 1243-1250.

MONTEIRO DA, ALMEIDA JA, RANTIN FT AND KALININ AL. 2006. Oxidative stress biomarkers in the freshwater characid fish, Brycon cephalus, exposed to organophosphorus insecticide Folisuper 600 (methyl parathion). Comp Biochem Physiol Part C 143: 141-149.

MOURA FR, BRENTEGANI KR, GEMELLI A, SINHORIN AP AND SINHORIN VDG. 2017. Oxidative stress in the hybrid fish jundiara (Leiarius marmoratus $\mathrm{x}$ Pseudoplatystoma reticulatum) exposed to Roundup Original $^{\circledR}$. Chemosphere 185: 445-451.

NEUMANN NF, STAFFORD JL, BARREDA D, AINSWORTH AJ AND BELOSEVIC M. 2001. Antimicrobial mechanisms of fish phagocytes and their role in host defense. Dev Comp Immunol 25: 807-825.

NIETHAMMER P, GRABHER C, LOOK AT AND MITCHISON TJ. 2009. A tissue-scale gradient of hydrogen peroxide mediates rapid wound detection in zebrafish. Nature 459: 996-999.

NORDBERG J AND ARNÉR ESJ. 2001. Reactive oxygen species, antioxidants, and the mammalian thioredoxin system. Free Radic Biol Med 31: 1287-1312.

OOST R, BEYER J AND VERMEULEN NPE. 2003. Fish bioaccumulation and biomarkers in environmental risk assessment: a review. Environ Toxicol Pharmacol 13: 137149.

ORUC EO, SEVGILER Y AND UNER N. 2004. Tissuespecific oxidative stress responses in fish exposed to 2,4D and azinphosmethyl. Comp Biochem Physiol C 137: 43-51.

PAIVA-OLIVEIRA EL, SILVA AC, SILVA RM, SEVENINI AS, MELO HA, LAGROTA-CANDIDO J AND QUIRICO-SANTOS T. 2010. Inflamassoma e sua repercussão clínica: revisão da literatura. Rev Cienc Med Biol 11: 96-102.

PARK JB. 2003. Phagocytosis induces superoxide formation and apoptosis in macrophages. Exp Mol Med 35: 325-335.

PAWELEC G, DERHOVANESSIAN E AND LARBI A. 2011. Immunosenescence and cancer. Crit Rev Oncol Hematol 75: $165-172$.

PIETTA P. 2000. Flavonoids as Antioxidants. J Nat Prod 63(7): 1035-1042.

SARDER MRI, THOMPSON KD, PENMAN DJ AND MCANDREW BJ. 2001. Immune responses of Nile tilapia (Oreochromis niloticus L.) clones: I. Non-specific responses. Dev Comp Immunol 25: 37-46.

SCANDALIOS JG. 2005. Oxidative stress: molecular perception and transduction of signals triggering antioxidant gene defenses. Braz J Med Biol Res 38: 9951014.

SCHIEBER M AND CHANDEL NS. 2014. ROS Function in Redox Signaling and Review. Oxidative Stress. Current Biol 24: 453-462.
SHAW AC, JOSHI S, GREENWOOD H, PANDA A AND LORD JM. 2010. Aging of the innate immune system. Curr Opin Immunol 22: 507-513.

SHI H, SUI Y, WANG X, LUO Y AND JI L. 2005. Hydroxyl radical production and oxidative damage induced by cadmium and naphthalene in liver of Carassius auratus. Comp Biochem Physiol C 140: 115-121.

SIES H. 1986. Biochemistry of oxidative stress. Angew Chem Int Ed Engl 25: 1058-1071.

SORG O. 2004. Oxidative stress: a theoretical model or a biological reality? Comptes Rendus Biologies 327: 649662.

STOREY KB. 1996. Oxidative stress: animal adaptations in nature. Braz J Med Biol Res 29: 1715-1733.

STUART LMAND EZEKOWITZ RAB. 2005. Phagocytosis: elegant complexity. Immunity 22: 539-550.

THERIAULT A, CHAO J-T, WANG Q, GAPOR A AND ADELI K. 1999. Tocotrienol: A review of its therapeutic potential. Clin Biochem 32: 309-319.

TSCHOPP J AND SCHRODER K. 2010. NLRP3 inflammasome activation: the convergence of multiple signalling pathways on ROS production? Nature Rev Immunol 10: 210-215.

UNDERHILL DM AND OZINSKY A. 2002. Phagocytosis of microbes: complexity in action. Annu Rev Immunol 20: 825-852.

VEAL EA, DAY AM AND MORGAN BA. 2007. Hydrogen peroxide sensing and signaling. Mol Cell 26: 1-14.

VIDER J, LEHTMAA J, KULLISAAR T, VIHALEMM T, ZILMER K, KAIRANE E, LANDO A, KARU T AND ZILMER M. 2001. Acute immune response in respect to exercise-induced oxidative Stress. Pathophysiol 7: 263270.

VOGT W. 1995. Oxidation of methionyl residues in proteins: Tools, targets, and reversal. Free Radical Biol Med 18: 93-101.

WANG C, YUE X, LU X AND LIU B. 2013. The role of catalase in the immune response to oxidative stress and pathogen challenge in the clam Meretrix meretrix C. Fish Shellfish Immunol 34: 91-99.

WEEKS SA AND WARINNER JE. 1986. Functional evaluation of macrophages in fish from a polluted estuary. Vet Immunol Immunopathol 12: 313-320.

WINSTON GW. 1991. Oxidants and antioxidants in aquatic animals. Comp Biochem Physiol C 100: 173-176.

WOOD ZA, POOLE LB AND KARPLUS PA. 2003. Peroxiredoxin evolution and the regulation of hydrogen peroxide signaling. Science 300: 650-653.

ZAMOCKY M, FURTMULLER PG AND OBINGER C. 2008. Evolution of catalases from bacteria to humans. Antioxid Redox Signal 10: 1527-1547. 